\title{
REVIEW
}

\section{Phytoplasma Casts a Magic Spell that Turns the Fair Poinsettia into a Christmas Showpiece}

\author{
Ing-Ming Lee, USDA, ARS, PSI, Molecular Plant Pathology Laboratory, BARC-West, Beltsville, Maryland \\ 20705-2318
}

Corresponding author: Ing-Ming Lee. imlee@asrr.arsusda.gov

Lee, I.-M. 2000. Phytoplasma casts a magic spell that turns the fair poinsettia into a Christmas showpiece. Online. Plant Health Progress doi:10.1094/PHP-2000-0914-01-RV.

\section{History of Poinsettia Cultivars}

The poinsettia, Euphorbia pulcherrima Wild, is a tropical plant indigenous to Mesoamerica

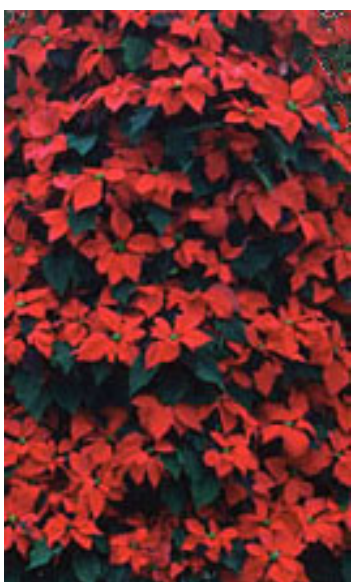

Fig. 1. Courtesy of Mike Klopmeyer of Ball FloraPlant, West Chicago.

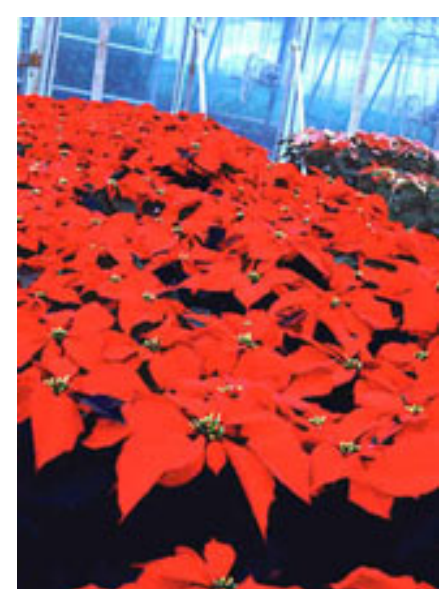

Fig. 2. Greenhouse production of commercial poinsettias. Courtesy of Mike Klopmeyer of Ball FloraPlant. 1997 . and tropical Mexico. It was cultivated by the Aztecs of Mexico, in the area near present-day Taxco, long before Christianity came to the Western Hemisphere. The brilliant 'flower' was beloved by natives and their kings as a symbol of purity (3). The flower was also processed by the Aztecs to make dye and the latex was used for a medicine against fever. Because poinsettias typically bloom during the Christmas holiday season, a group of Franciscan priests who were settled near Taxco in the 17th century began to use the brilliant flowers in the Fiesta of Santa Pesebre, a nativity procession. This is the first known incidence of poinsettias being used for holiday celebrations.

Poinsettias were first introduced into the United States in 1825 by Joel Robert Poinsette while he served as the first U. S. Ambassador to Mexico. Poinsette, a renowned botanist, had several plants sent to his home in Greenville, South Carolina, which he later distributed to various botanical gardens and his horticultural friends (3). Robert Buist, a nurseryman, first sold the plant as Euphorbia pulcherrima. However, the name poinsettia has become the accepted name in English speaking countries. Today, poinsettias are one of the most important floricultural crops in the United States (Figs. 1 and 2). Total U.S. poinsettia production was valued at \$325 million in

Poinsettias are native to southern Mexico and Mesoamerica and, unlike today's commercial cultivars, they grow into straight and tall trees. Often these trees can reach heights up to 10 feet tall. Through selection and breeding by growers, many cultivars have been developed in the United States and Europe $(3,11)$. Two morphotypes of poinsettia cultivars are grown commercially (10): one is a restricted-branching morphotype characterized by strong apical dominance and few axillary shoots and 'flowers' (actually modified leaves called bracts); the other is a freebranching morphotype characterized by weak apical dominance and many axillary shoots and 'flowers' (Figs. 3-5). In the early 1900s most poinsettia plants were sold as fresh cut flowers, notably by the Ecke family in Southern California (3). The modern era of poinsettia culture began in 1923 with the introduction of the seedling cultivar selected and developed mainly by Paul Ecke of Encinitas, California. This cultivar was shorter in stature and produced a more attractive branching plant. In 1945, a selection called "Improved Albert Ecke" was introduced; this plant branched more freely and produced a greater percentage of perfect bracts. In 1967, a self-branching cultivar called Annette Hegg was introduced by Thormod Hegg of Lier, Norway (11). Poinsettias entered a new era when more free-branching cultivars with improved lasting foliage retention characteristics were introduced in the United States as well as in Europe. These free-branching cultivars, which were ideal for developing multiflowered potted plants, comprise the majority of commercial cultivars propagated today. 

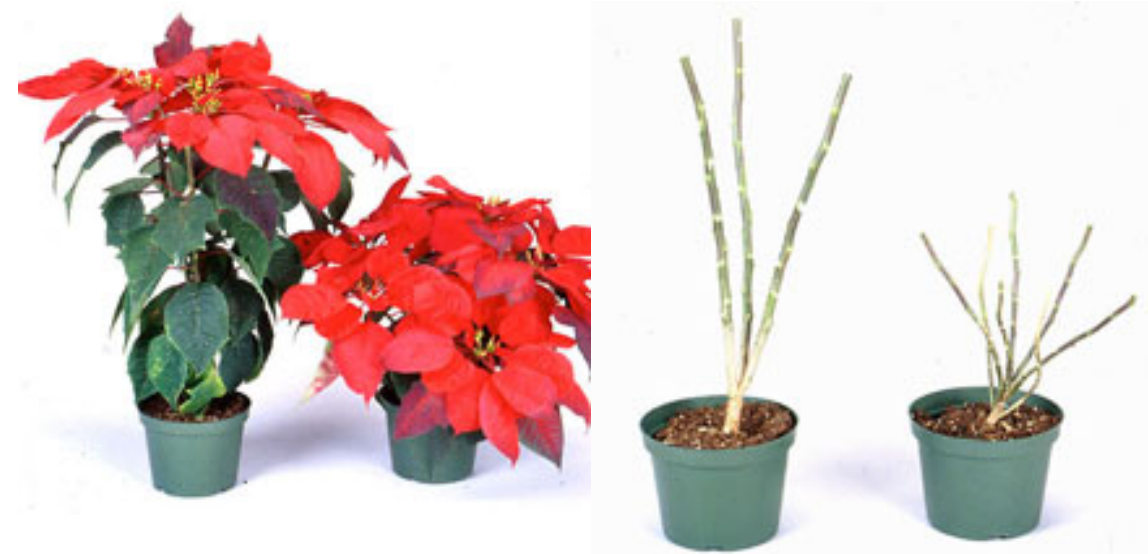

Fig. 3. Restricted- (left) and free-branching Fig. 4. Branching types of restricted- (left) (right) poinsettia morphotypes of cultivar and free-branching (right) poinsettia

Jolly Red. The restricted plant was derived plants. Courtesy of Mike Klopmeyer of Ball from a somatic embryo. Courtesy of Mike FloraPlant Klopmeyer of Ball FloraPlant.

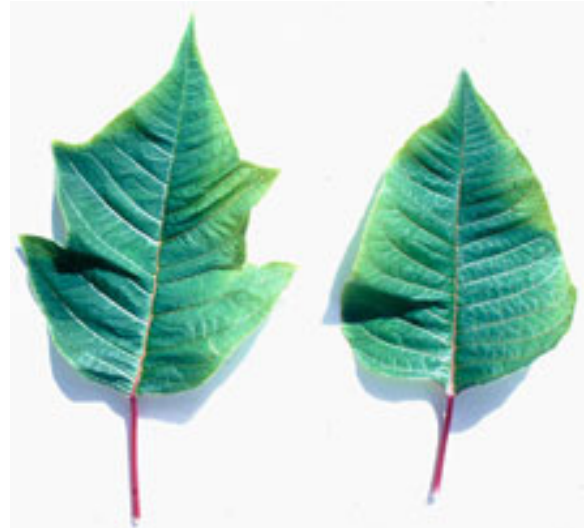

Fig. 5. Leaf morphology of restricted- (left) and free-branching (right) poinsettias.

\section{Mystery of Free-Branching Growth Habit}

Probably since 1923, a secret "friend," unbeknownst to the growers, has dwelt inside poinsettias, "casting magic spells" on poinsettias to produce free-branching morphotypes. The presence of an endophytic biological agent was suspected when horticulturists noticed that the ability of free-branching cultivars to induce axillary shoots and to produce a desirable multiflowered canopy was lost after poinsettias had been subjected to heat treatment, meristem tissue culture, or somatic embryogenic tissue culture, processes traditionally used to eliminate potential pathogens including poinsettia mosaic virus (PnMV) (5). The free-branching ability, however, could be restored when the treated plants were approach-grafted onto free-branching stock plants (10). At first, PnMV was suspected to be the agent contributing to the induction of freebranching because the virus was associated with all free-branching cultivars and because heat treatment or meristem tip culture of plants eliminated both the virus and the free-branching growth habit. But the virus was also found in restrictedbranching cultivars (8). Early attempts to identify a biological agent other than these viruses failed (2).

\section{Proof of Phytoplasmal Etiology}

Since excessive branching of host plants is one of the characteristic symptoms induced by phytoplasmal infections, a phytoplasma etiology of the free-branching morphotype was suspected. During 1995-1997, in collaboration with Ball FloraPlant scientists (West Chicago, IL) (8, 9), we were able to detect the presence of phytoplasmas in all of the 20 commercial free-branching poinsettia cultivars using phytoplasma-specific primers developed based on phytoplasma $16 \mathrm{~S}$ rRNA gene sequences in a nested PCR reaction (4). With dodder as a bridge, connecting vascular tissues between poinsettia and periwinkle, we transmitted phytoplasmas from a free-branching poinsettia plant into healthy periwinkle, a non-host of PnMV (Fig. 6). After 3-6 months phytoplasma infection of periwinkle was evident and plants developed bushy growth type (Figs. 6, 7a, and 7b). ELISA tests indicated that no detectable PnMV was present in these plants. We then transmitted the phytoplasmas from symptomatic periwinkle plants, via dodder, into a PnMV-free restricted branching poinsettia, which subsequently developed a free-branching form after 3-4 months. The phytoplasma, not the virus, was subsequently detected in the inoculated poinsettia. Identities of the phytoplasma present in all the tested plants were confirmed by RFLP analysis of the PCR- amplified phytoplasma 16S rDNA sequences (8). We fulfilled modified Koch's postulates in which isolation of the pathogen, an unculturable phytoplasma, was accomplished using a living host (periwinkle, a nonhost of PnMV) and the identity of the pathogen was confirmed based on molecular analyses. Therefore, 
we concluded that phytoplasma is the hidden 'friend' that may have secretly dwelt in selected free-branching poinsettia cultivars and actually contributed to the induction of axillary shoots in free-branching poinsettia cultivars.

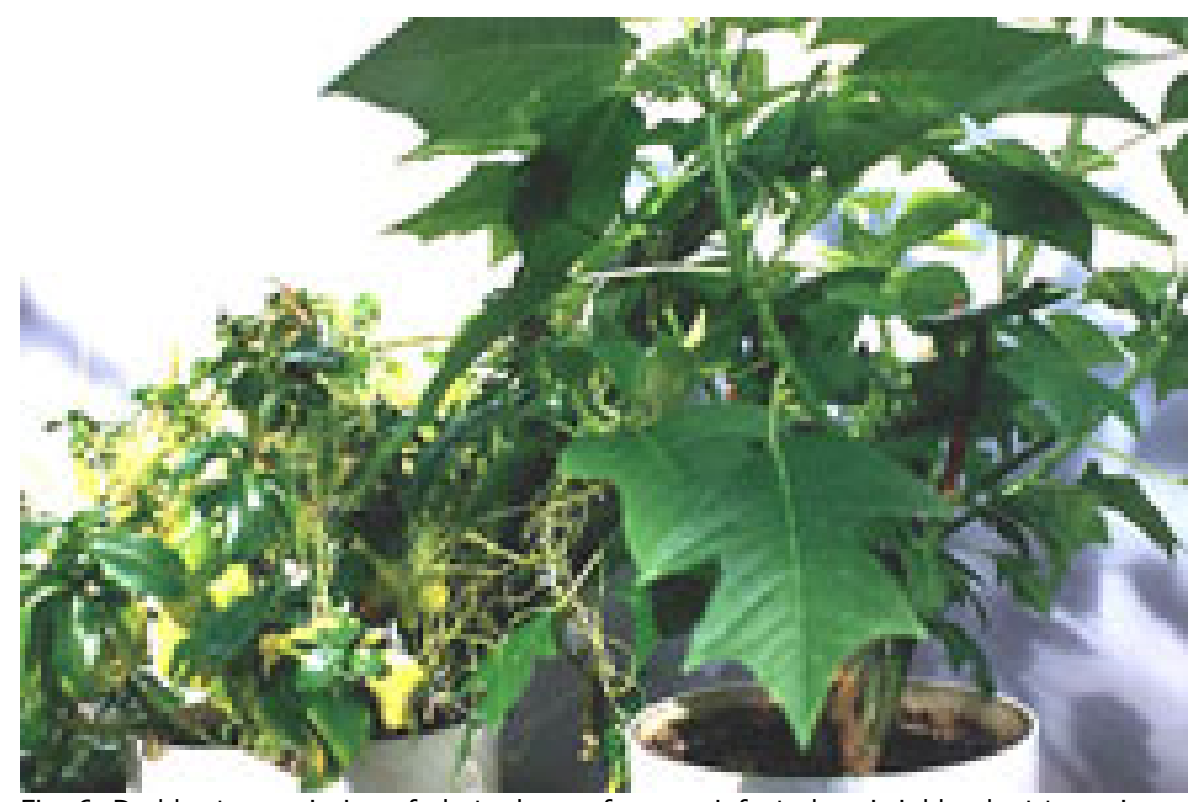

Fig. 6. Dodder transmission of phytoplasma from an infected periwinkle plant to a virusfree restricted-branching poinsettia plant (click image for expanded view).

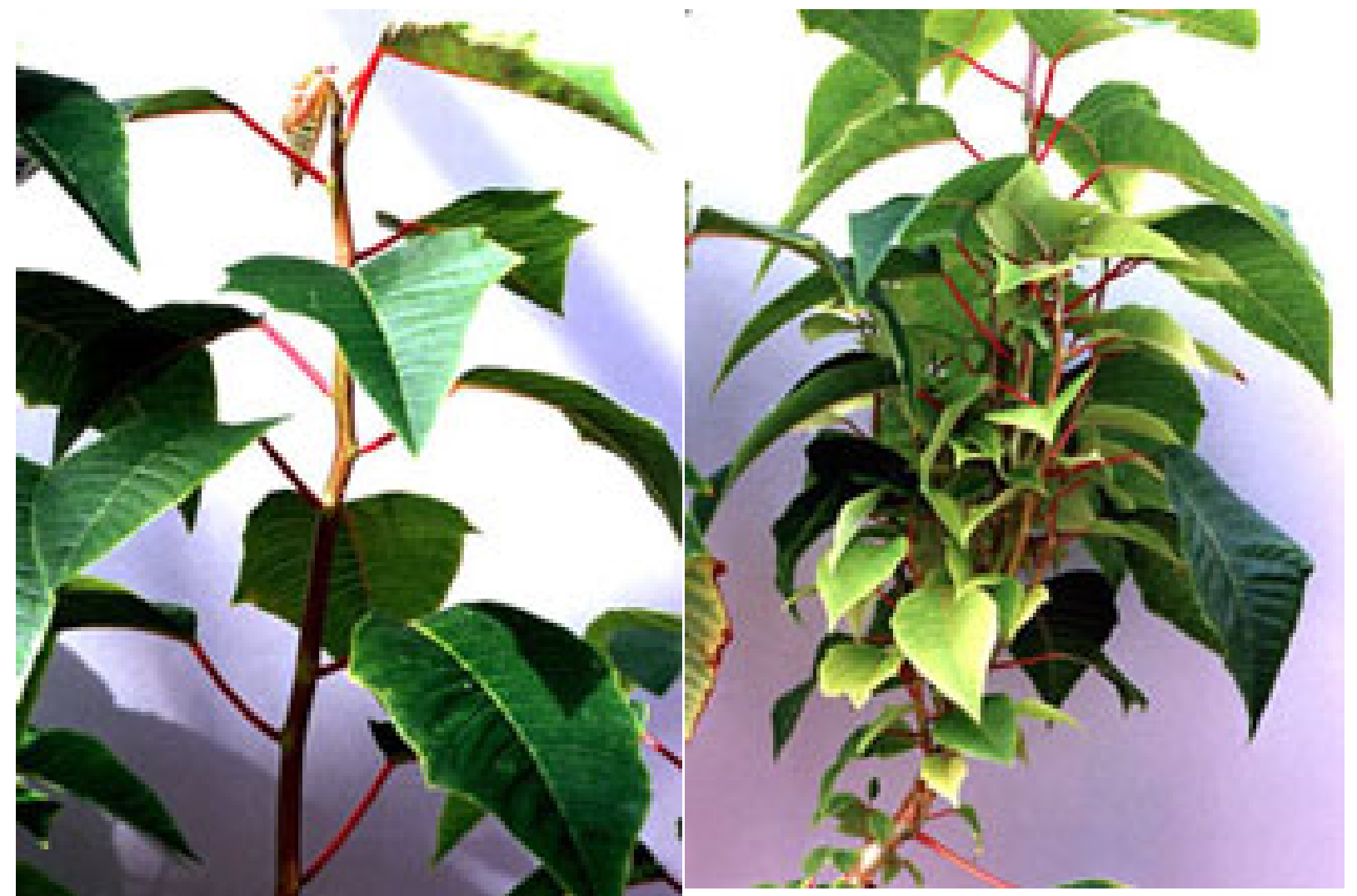

Fig. 7a. Restricted-branching morphotype.

Fig. 7b. Free-branching morphotype induced by infection with phytoplasma

The procedure described above provides the growers, for the first time, the ability to produce PnMV-free poinsettias without losing the free-branching growth habit. 


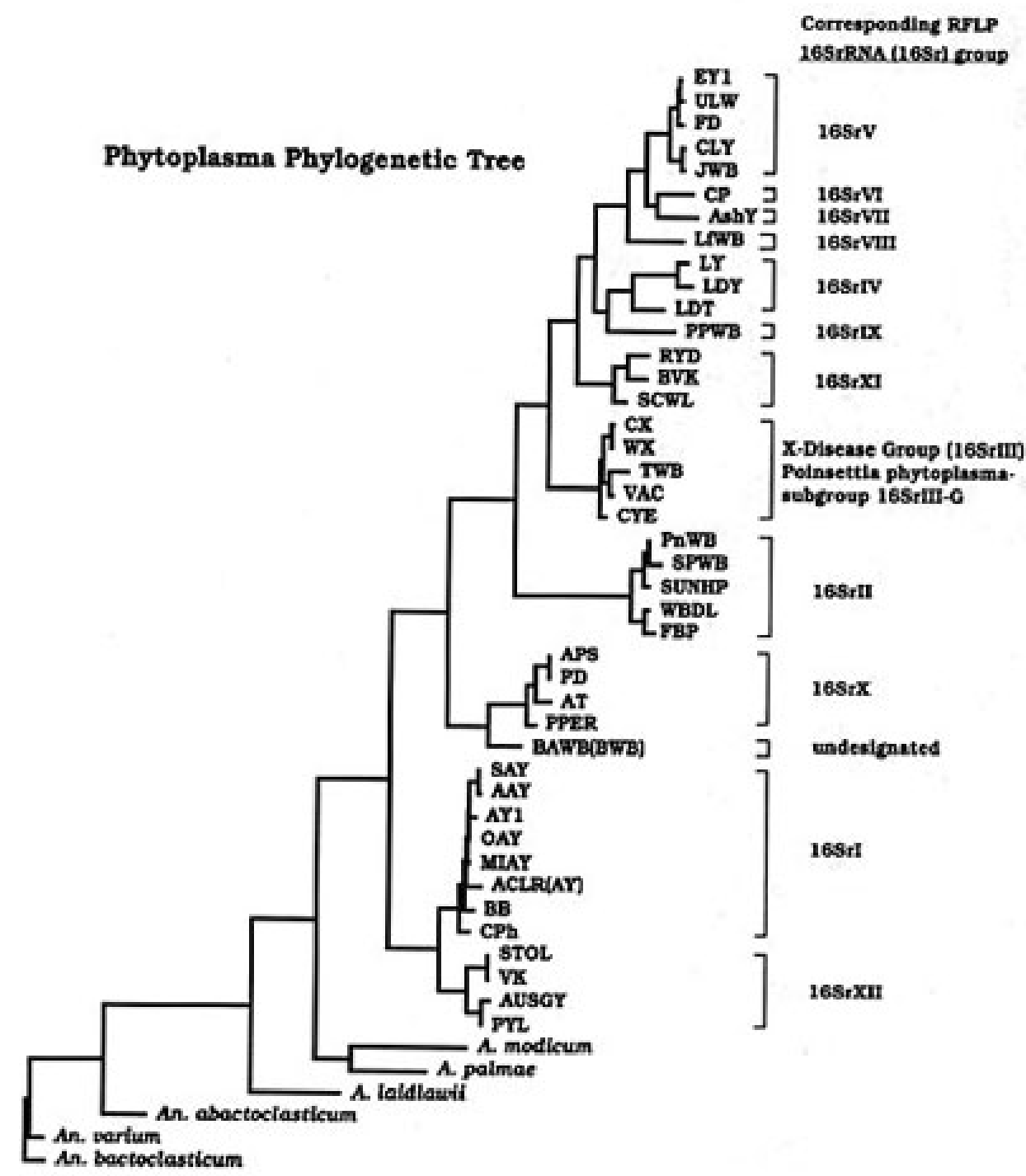

The primary phytoplasma associated with free-branching poinsettia cultivars was identified as belonging to the peach X-disease phytoplasma group (16S rRNA group III or 16SrIII), subgroup 16SrIII-H, according to the classification scheme proposed by Lee et al. $(6,7)$ (Figure 8 ). Phytoplasmas in this subgroup are most closely related to $\mathrm{X}$-disease (subgroup 16SrIII-A) and spirea stunt (subgroup 16SrIII-E) phytoplasmas. It is now known that the poinsettia phytoplasma is associated with freebranching poinsettia cultivars developed in the United States as well as in Europe. Other phytoplasmas (related to members of the aster yellows phytoplasma group and to other members of peach X-disease group) occasionally co-infect with the major poinsettia phytoplasma $(1,8)$. The poinsettia branch-inducing phytoplasma (subgroup 16SrIII-H) has not been found in association with any other plant hosts in nature. Although most phytoplasmas are transmitted in nature by plant-feeding insects, it is not yet known whether the poinsettia phytoplasmas are spread by an insect vector.

Fig. 8. Phytoplasma phylogenetic tree constructed by parsimony analysis of full $16 \mathrm{~S}$ rRNA gene sequences from 42 phytoplasmas and 6 members of the class Mollicutes. Phytoplasmas: EY1, American elm yellow; ULW, French elm yellows; FD, Flavescence dorée; CLY, Cherry lethal yellowing; JWB, Jujube witches'-broom; CP, Clover proliferation; AshY, Ash Yellows; LfWB, Loofah witches'-broom; LY, Coconut lethal yellowing; LDY, Yucatan coconut lethal decline; LDT, Tanzanian coconut lethal decline; PPWB, Pigeon pea witches'-broom; RYD, Rice yellow dwarf; BVK, from leafhopper Psammotettia cephalotes; SCWL, Sugarcane whiteleaf; CX, Canada peach X-disease; WX, Western X-disease; TWB, Tsuwabuki witches'- broom; VAC, Vaccinium witches'-broom; CYE, Clover yellow edge; PnWB, Peanut witches'- broom; SPWB, Sweet potato witches' -broom; SUNHP, Sunn hemp witches'-broom; WBDL, Lime witches'-broom (Candidatus Phytoplasma aurantifolia); FBP, Faba bean phyllody; APS, Apple proliferation; PD, Pear decline/ Italy; AT, Apple proliferation; PPER, Peach decline; BAWB, Buckthorn witches'broom; SAY, Western severe aster yellow; AAY, American aster yellow; AY1, Maryland aster yellow; OAY, Oenothera aster yellow; MIAY, Michigan aster yellow; ACLR (AY), Apricot chlorotic leafroll; BB, Tomato big bud; CPh, Clover phyllody; STOL, Stolbur of pepper; VK, Vergilbungskrankheit (grapevine yellows); AUSGY, Australian grapevine yellow (Candidatus Phytoplasma australiense) and PYL, Phormium yellow leaf. Other members of Mollicutes: Genus Acholeplasma: A. modicum, A.palmae and A. laidlawii; Genus Anaeroplasma: An. abactoclasticum, An. varium, and An. bactoclasticum. 


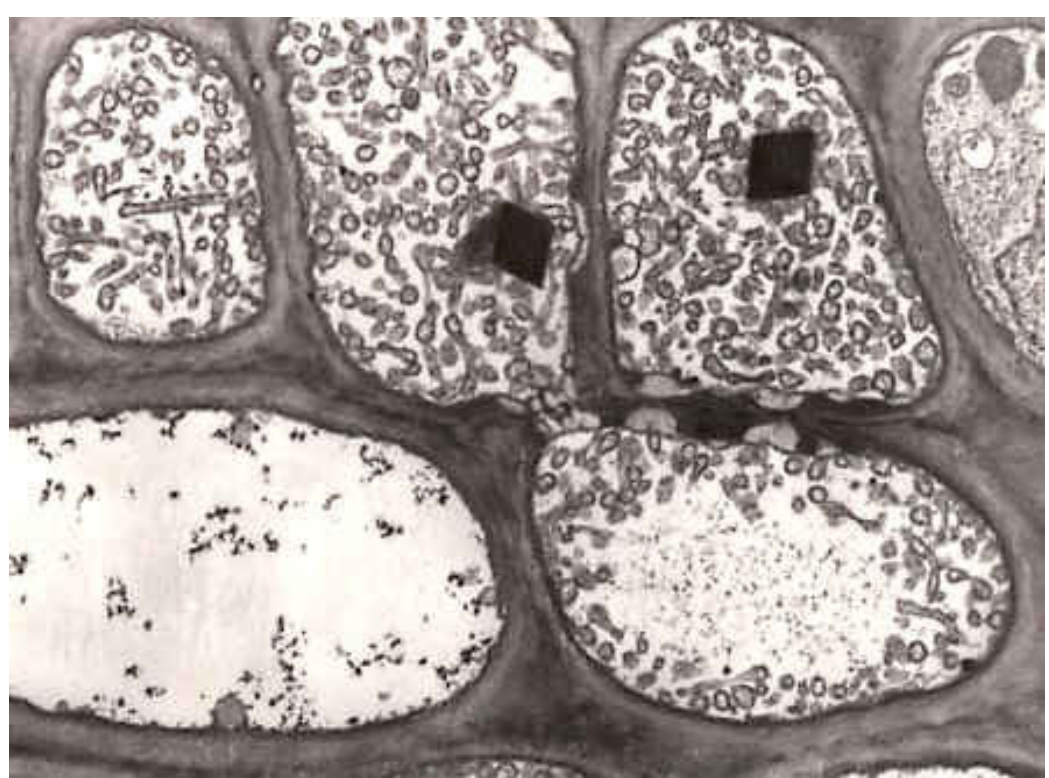

Fig. 9. Electron microscopy (x6000) of cross-section of gladiolus phloem tissue infected with phytoplasma. Numerous phytoplasma bodies are apparent in the upper sieve elements. The sieve element in the lower left-hand corner is apparently free of phytoplasma bodies (courtesy of Assunta Bertaccini) (click image for expanded view).
Phytoplasmas (previously called MLOs) are important plant pathogens as they are associated with diseases in several hundred plant species worldwide. Diseases associated with the presence of phytoplasmas in phloem (Fig. 9) typically exhibit an array of symptoms suggestive of profound disturbances in the normal balance of plant hormones. Symptoms in plants include sterility of flowers, virescence (the development of green flowers and loss of normal flower color), phyllody (the development of floral parts into leafy structures), proliferation of axillary shoots or auxiliary shoots resulting in witches'-broom appearance, generalized stunting and decline, bunchy appearance of growth at the stems, yellowing, phloem necrosis, and dieback of branches in woody plants. In general, the range of symptoms attributed to phytoplasmal infection are indicative of detrimental effects on plants. The damage due to the growth disorders induced by phytoplasmal infections ranges from partial reduction in yield and quality to nearly total loss of the crop. The subtle interactions between the phytoplasma and

poinsettia result in dwarfing and moderate branching growth habit, which happens to be a trait that poinsettia growers desire. Technically, free-branching is a disease symptom in poinsettias. But, like the virus associated with classical colorbreaking of tulip petals, the poinsettia phytoplasma is beneficial to growers, generating multi-flowered Christmas showpieces and \$325 million annually.

\section{Literature Cited}

1. Abad, J. A., Randall, C., and Moyer, J. W. 1997. Genomic diversity and molecular characterization of poinsettia phytoplasmas. Phytopathology 87:S1.

2. Dole, J. M., Wilkins, H. F., and Desborough, S. L. 1993. Investigation on the nature of a graft-transmissible agent in poinsettia. Can. J. Bot. 71:1097-1101.

3. Ecke Jr., P., Matkin, O. A., and Hartley, D. E. 1990. The Poinsettia Manual, 3rd ed. Paul Ecke Poinsettias, Encinitas, CA.

4. Gundersen, D. E. and Lee, I.-M. 1996. Ultrasensitive detection of phytoplasmas by nested- PCR assays using two universal primer pairs. Phytopathologia Mediterranea 35:144-151.

5. Koenig, R., Lesemann, D. E., and Fulton, R. W. 1986. Poinsettia mosaic virus. AAB Descriptions of Plant Viruses, No. 311.

6. Lee, I.-M., Gundersen-Rindal, D. E., Davis R. E., and Bartoszyk, I. M. 1998. Revised classification scheme of phytoplasmas based on RFLP analyses of 16S rRNA and ribosomal protein gene sequences. Int. J. Syst. Bacteriol. 48:1153-1169.

7. Lee, I.-M., Hammond, R. W., Davis, R. E., and Gundersen, D. E. 1993. Universal amplification and analysis of pathogen 16S rDNA for classification and identification of mycoplasmalike organisms. Phytopathology 83: 834-842.

8. Lee, I.-M., Klopmeyer, M., Bartoszyk, I. M., Gundersen-Rindal, D. E., Chou, T.-S., Thomson, K. L. and Eisenreich, R. 1997. Phytoplasma induced free-branching in commercial poinsettia cultivars. Nature Biotechnology 15:178-182.

9. Lee, I.-M., Tiffany, M., Gundersen, D. E., and Klopmeyer, M. 1995. Phytoplasma infection: A beneficial factor for production of commercial branching poinsettia cultivars? Phytopathology 85:1179.

10. Stimart, D. P. 1983. Promotion and inhibition of branching in poinsettia in grafts between self-branching and non-branching cultivars. J. Amer. Soc. Hort. Sci. 108:419-422.

11. Strømme, E. 1994. The Scientific basis of poinsettia production. The Agricultural University of Norway, Aas-NLH, Norway. 